既に膿汁が貯留していた群を自然発生副鼻腔炎群とし た、ネンブタール静脈麻酔下に摘出した副鼻腔粘膜を 細切後ホモジナイズし, 遠沈操作を繰り返し, 膜成分 のみの视査を用いて，蛋白定量および Na-K ATP ase, $\mathrm{Mg}$ ATP ase 活性を分光器を用いて測定した. ま た, 摘出した粘膜は, 光顕用と電顕用とし組織化学的 にその局在を検討した。

結果 i ) Na-K ATP aseは, 正常 $43.2 \pm 8.0(\mu \mathrm{gp} /$

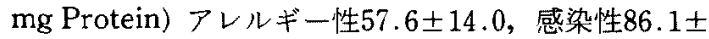
12.6 , 自然発生 $82.6 \pm 10.80$ 結果で, 正常と感染性扔 よび自然発生副鼻腔炎群に有意差 $(P<0.05)$ を認め た. ii ) Mg ATP aseは, 正常63.7士10.6, アレルギ 一性 $40.8 \pm 9.5$, 感染性 $73.9 \pm 21.0$, 自然発生 $66.7 \pm 9.9$ の結果で有意差はなかった。しかし，アレルギー性副 鼻腔炎では低下する傾向を認めた。 iii） Na-K ATP aseは，正常，アレルギ一では，特に強く染色される部 位は認めなかったが，副鼻腔炎で注腺の内腔側に強く
染色された．iv）Mg ATP aseは，線毛上皮，血管内 皮細胞，腺細胞に強く染色された。

考察 i） Na-K ATP aseは，炎症とともに增成し た腺細胞に強く染色された分泌穴進と関係している。 ii）Mg ATP aseは，線毛上皮だけではなく血管・腺 細胞にも存在し, 線毛運動との関係を明らかにするた めには上皮のみを採取してその変化を検討しなければ ならない. 質問 坂倉康夫 (三重大). Na-K ATP aseの局在性について。応答 Na-K ATP aseは 膜のどの部位にも存在している. 分泌が充進すれば, $\mathrm{Na}-\mathrm{K} \mathrm{ATP}$ aseも六進すると考える。質問 鈴村 恵理 (三重大)。 ウサギ，自然発生副鼻腔炎の率と，そ の鼻汁中の細菌，好酸球の有無。応答実験動物 学の成書によると, 自然発生副鼻腔炎 (スノッフル) は数\%存在する。鼻汁中好中球好酸球は調べていない。 起因菌は家鬼の常在菌であった。

\title{
166. 鼻・副鼻腔腺癌の組織発生
}

\author{
——病理組織学的検討を中心に一
}

小川晃弘・内藤好宏・川上晋一郎・増田 游（岡山大） 宇野欽哉・小池聰之（四国がんセンター）

目的一般に上顎洞の粘膜が円柱上皮であるにもか かわらず上箱癌は，㭱とんどが扁平上皮澏であり，腺

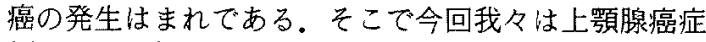
例について検討し上顎癌の組織発生について考察を加 えた。

方法 国立病院四国がんセンター及び岡山大学耳鼻 咽喉科での853症例の鼻・副鼻腔の生検・手術材料のj 532腺癌症例被蓋上皮型腺癌 8 症例, 腺扁平上皮癌 3 症例, 分泌腺型腺癌 21 症例と細分類し, 扁平上皮癌 及び良性症例とも比較しながら病理組織学的に検討し た。すなわち $\mathrm{H}-\mathrm{E}$ 染色を基本とし，腺癌20症例につい てはPAS, Alcian blue 染色を追加, 症例によっては 免疫組織化学的手法 $(\mathrm{ABC}$ 法)により CEA, サイトケ ラチンを検索した。染色態度は, 円柱上皮を被蓋上皮 部, 分泌腺導管部, 腺房部に分けて検討した。

結果 20例の腺癌についての PAS 陽性が13例，Alcian blue 陽性が13例であり, 前者は被蓋上皮型腺癌で 乳頭状あるいは管状腺癌部に強陽性例が多く, 後者は 腺様䇾胞癌で強陽性例が多く間質や腺房部に強く陽性 を認めた。免疫組織化学的染色による CEA を見ると， 被蓋上皮型腺漓では，いずれも被蓋上皮部に強く陽性 を認める症例が多く $(80 \%)$, 分泌腺型腺癌では導管上 皮部に強く陽性を認め $(90 \%)$, 腺扁平上皮癌症例にお
いては全例で腺癌部の遊離緑及じ扁平上皮癌の角化部 にCEA 陽性を認めた。サイトケラチンは腺癌症例全 体を通じて陽性症例が少ないが，粘液表皮癌の 1 例と 腺扁平上皮癌とした 3 例中 2 例の扁平上皮癌の部分が 強陽性であった。 その他の病理組織学的所見について は, 腺癌20症例中, 乳頭状増殖は 8 例に, ポリープ状 增殖は 7 例に, oncocytic change は 4 例に, 炎症細胞 浸潤は13例に認められたが非癌症例においてもこれら の病変を認めた。また被蓋及び分泌腺円柱上皮に認め られる異形成は鼻・副鼻腔全症例の0.9\%で扁平上皮異 形成の $6.2 \%$ に比して非常に少なく腺癌の前癌病変を 捉えることはできなかった。

結論 以上の結果加被蓋上皮型腺癌及び腺扁平上 皮癌は被蓋円柱上皮から発生し，この両者の間には密 接な関係があることがわかった。 そして腺癌の多数を 占める分泌腺型腺癌は分泌腺に由来することが確かめ られた。分泌腺の場合, 導管部加発生する場合々腺 房部から発生する場合もがあることが明らかになっ た. 質問 毛利 学 (大阪霜大). 検討した症例は, 血清中のCEA 濃度の測定を行っているか。応答 CEA は一部の症例のみについては, 血中濃度も溳定し ているが，組織 CEA と必ずしも同調してない. 